\title{
Correction to: Assessment of long-term sickness absence: content and face validity of a new questionnaire based on qualitative data from nominal groups
}

Kaat Goorts ${ }^{1 *}$, Charlotte Vanovenberghe ${ }^{1}$, Charlotte Lambreghts ${ }^{1,2}$, Eline Bruneel ${ }^{3}$, Dorina Rusu ${ }^{4,5}$, Marc Du Bois ${ }^{1}$, Sofie Vandenbroeck ${ }^{1,2}$ and Lode Godderis ${ }^{1,2}$

\section{Correction to: BMC Med Res Methodol (2019) 19:205} https://doi.org/10.1186/s12874-019-0852-3

In the original publication of this article [1] the author Marc Du Bois was omitted. In this correction article the author and the corresponding details are provided. The publisher apologizes to the readers and authors for the inconvenience.

The original publication has been corrected.

\begin{abstract}
Author details
'Katholieke Universiteit Leuven, Centre for Environment and Health, Kapucijnenvoer 35/5, 3000 Leuven, Belgium. ${ }^{2}$ Idewe, External Service for Prevention and Protection at Work, Interleuvenlaan 58, 3001 Heverlee, Belgium. ${ }^{3}$ Vlaams Patiëntenplatform vzw, groenveldstraat 15, 3001 Heverlee, Belgium. ${ }^{4}$ Département des Sciences de la Santé publique, Université de Liège, Médecine du Travail et environnementale, Liège, Belgium.

${ }^{5}$ SPMT-ARISTA, External Service for Prevention and Protection at Work, Rue Royale 196, 1000 Brussels, Belgium.
\end{abstract}

Published online: 04 December 2019

\section{Reference}

1. Goorts K, Vanovenberghe C, Lambreghts C, et al. Assessment of long-term sickness absence: content and face validity of a new questionnaire based on qualitative data from nominal groups. BMC Med Res Methodol. 2019;19: 205. https://doi.org/10.1186/s12874-019-0852-3.

Full list of author information is available at the end of the article

(c) The Author(s). 2019 Open Access This article is distributed under the terms of the Creative Commons Attribution 4.0 International License (http://creativecommons.org/licenses/by/4.0/), which permits unrestricted use, distribution, and reproduction in any medium, provided you give appropriate credit to the original author(s) and the source, provide a link to the Creative Commons license, and indicate if changes were made. The Creative Commons Public Domain Dedication waiver (http://creativecommons.org/publicdomain/zero/1.0/) applies to the data made available in this article, unless otherwise stated. 